\title{
DAMPAK PERKEMBANGAN KAWASAN WISATA MUSEUM KARST INDONESIA TERHADAP KONDISI LINGKUNGAN DI DUSUN MUDAL, GEBANGHARJO, PRACIMANTORO, WONOGIRI \\ (Impact of the Indonesian Karst Museum Tourism Areas on Environmental Conditions in Dusun Mudal, Gebangharjo, Pracimantoro, Wonogiri)
}

\author{
Dedy Kunardi*, Sudrajat, dan Rika Harini \\ Program Studi Ilmu Lingkungan, Sekolah Pascasarjana Universitas Gadjah Mada, Yogyakarta. \\ *Penulis korespondensi. Email: kunardi0007@gmail.com.
}

Diterima: 31 Mei 2018

Disetujui: 6 Desember 2018

\begin{abstract}
Abstrak
Kawasan wisata Museum Karst Indonesia sebagai salah satu kawasan Kawasan Geopark UNESCO - Gunungsewu yang berada di Gebangharjo, Pracimantoro, merupakan salah satu objek wisata potensial yang berada di Kabupaten Wonogiri. Evaluasi untuk mencapai pariwisata yang berkelanjutan sangatlah penting meliputi dampak sosial, ekonomi, dan lingkungan. Tujuan dari penelitian ini adalah mengidentifikasi perkembangan wisata yang ada di kawasan wisata Museum Karst Indonesia, mengkaji keterlibatan masyarakat dalam kegiatan pendukung wisata setempat, dan menganalisis dampak lingkungan dari adanya kawasan wisata Museum Karst Indonesia terhadap kondisi lingkungan fisik dan sosial ekonomi masyarakat lokal. Perolehan data dilakukan dengan metode observasi, penyebaran kuesioner, dan wawancara. Hasil ditampilakan menggunakan analisis distribusi frekuensi terhadap skala likert. Perkembangan kawasan wisata MKI masih berada pada tahap awal perkembangan. Masyarakat Dusun Mudal masih sedikit yang terlibat dalam mendukung kegiatan wisata, seperti tenaga kerja, pedagang, penyedia jasa penginapan. Perubahan kondisi sosial ekonomi masyarakat dan kondisi lingkungan fisik di Dusun Mudal tidak begitu dirasakan (kecil). Kedepannya masih diperlukan upaya peningkatan kesejahteraan masyarakat di sekitar kawasan wisata MKI dengan meningkatkan keterlibatan masyarakat dalam kegiatan pendukung wisata.
\end{abstract}

Kata kunci: kawasan karst, geopark, wisata khusus, dampak sosial ekonomi.

\begin{abstract}
Tourism area of Karst Museum of Indonesia as apart of UNESCO Global Geopark Gunungsewu located in Gebangharjo, Pracimantoro is one of tourism object of Wonogiri Regency. Evaluation to achieve a sustaibable tourism is important, involve the social, economic, and environmental impact. The purpose of this research are to analize the development in the tourism area of Karst Museum of Indonesia, to study the activities of the community in supporting tourism activities in Karst Tourism Area of Indonesia Museum, and to analyze the impact of the Karst Indonesia Museum's tourism on the physical social and economic condition of the local community. Data was collected by observation technique, questionnaire distribution, and interview. The result analized by frequency distribution analysis of likert scale questionnaire. The results show that the development of tourist areas is still at an early stage of development. The Mudal community is still a bit involved in supporting tourism activities, such as labor, traders. Transformation in socio-economic and environmental conditions in Mudal Village are in small impact category. In the future still needed efforts to improve the community around the tourist area of MKI by increasing community involvement in tourism support activities.
\end{abstract}

Keywords: karst area, geopark, special tourism, socioeconomic impact, involvement.

\section{PENDAHULUAN}

Kawasan Karst Gunung Sewu di Gunungkidul, Wonogiri dan Pacitan telah ditetapkan oleh UNESCO sebagai UNESCO Global Geopark Gunung Sewu pada tahun 2015 (Amelia, 2015). Keberadaan Kawasan Wisata Museum Karst Indonesia yang berada di Desa Gebangharjo, Pracimantoro telah menjadi salah satu dari 5 (lima) objek wisata potensial yang berada di Kabupaten Wonogiri (Nugroho dkk., 2015). Pembangunan pariwisata memiliki peran penting terhadap sektor ekonomi, sosial budaya dan lingkungan ( Supardi, 2003; Briassoulis dan van der Straaten, 2009; Nugroho, 2011). Pariwisata menjadi sektor yang terus berkembang dan berpotensi berdampak terhadap lingkungan, sehingga diperlukan prinsip pembangunan yang berkelanjutan dalam pengembangannya. Pengembangan sektor pariwisata di Indonesia secara umum bergantung pada kondisi alam dan warisan budaya masyarakat. Berkaitan dengan kondisi tersebut maka diperlukan evaluasi agar dapat mencapai pariwisata yang berkelanjutan, meliputi dampak terhadap kondisi 
sosial, ekonomi, dan lingkungannya (Theobald, 2005; Williams dan Alan, 2015). Kawasan Wisata Museum Karst Indonesia di Kecamatan Pracimantoro ditetapkan melalui Peraturan Daerah Kabupaten Wonogiri Nomor 9 Tahun 2011 tentang RTRW Kabupaten Wonogiri Tahun 2011- 2031. Kawasan wisata tersebut termasuk dalam kategori pariwisata buatan. Hal yang menarik dari kawasan wisata ini selain adanya museum juga terdapat wisata alam berupa bentang lahan karst. Goa-goa yang ada di kawasan wisata tersebut di antaranya yaitu Goa Sodong, Goa Tembus, dan Goa Gilap, Goa Potro Bunder, Luweng Sapen, dan Goa Mrico.

Kegiatan pembangunan hendaknya memiliki keseimbangan antara ekonomi, sosial dan ekologi. Hal ini sejalan dengan hakekat dari pembangunan yaitu suatu proses sosial yang bersifat integral dan menyeluruh baik dari pertumbuhan ekonomi maupun perubahan sosial demi terwujudnya kemakmuran masyarakat (Supardi, 2003). Lingkungan fisik dan sosial ekonomi masyarakat dapat saja berubah dengan adanya suatu kegiatan atau proyek yang sedang berlangsung.

Pada tahun 1997, World Commision Protected Area (WCPA) sebagai komisi yang bernaung di bawah International Union for Conservation of Nature (IUCN) telah mendorong dilakukannya perlindungan ekosistem karst di seluruh dunia dengan beberapa pertimbangan. Pertimbangan yang terkait dengan ekologi yaitu bahwa karst merupakan habitat flora dan fauna langka; karst sebagai kawasan mineral langka (tidak terbarukan) dan memiliki bentang alam yang unik. Karst menjadi bagian penting kawasan prasejarah dan sejarah kebudayaan dan sebagai tempat untuk penelitian berbagai disiplin ilmu pengetahuan. Bagi masyarakat lokal, karst dapat berfungsi sebagai wilayah religi dan spiritual, area perkebunan dan kegiatan industri khusus. Fungsi karst yang juga penting bagi kehidupan di atasnya yaitu bahwa karst sebagai kawasan kunci untuk mempelajari hidrologi kawasan. Pertimbangan terakhir yang menjadikan karst perlu dilindungai yaitu bahwa karst telah menjadi tempat rekreasi dan wisata yang menarik di dunia.

Penelitian terkait dengan dampak dari keberadaan Kawasan Wisata Museum Karst Indonesia (MKI) ini menjadi penting untuk dilakukan mengingat daerah dikembangkannya kawasan tersebut berada pada bentang lahan karst dimana memiliki keterbatasan daya dukung lingkungan (lahan dan air) tetapi sangat rentan terhadap kerusakan dan pencemaran lingkungan. Penelitian terdahulu di kawasan wisata ini belum mengkaji perkembangan dan dampak-dampak yang ditimbulkannya (aspek sosial, ekonomi maupun lingkungannya). Berdasarkan latar belakang tersebut dilakukan penelitian dengan tujuan mengidentifikasi perkembangan wisata yang ada di kawasan wisata MKI, mengkaji keterlibatan masyarakat dalam kegiatan pendukung wisata setempat, dan menganalisis dampak lingkungan dari adanya kawasan wisata MKI terhadap kondisi lingkungan fisik dan sosial ekonomi masyarakat lokal.

\section{METODE PENELITIAN}

\section{Waktu dan Lokasi}

Penelitian dilakukan pada Bulan Januari sampai dengan Maret 2018. Lokasi penelitian berada di Dusun Mudal, Desa Gebangharjo, Kecamatan Pracimantoro, Kabupaten Wonogiri, provinsi Jawa Tengah.

\section{Prosedur}

Data diperoleh melalui teknik metode triangulasi, yaitu: wawancara, kuesioner, dan pengamatan langsung selama periode penelitian. Populasi penelitian yaitu 161 rumah tangga (keluarga) yang berdomisili di Dusun Mudal. Sampel sebanyak 62 keluarga diambil berdasarkan pengelompokan keterlibatannya dalam kegiatan wisata menggunkan perhitungan Pendataan Slovin dengan derajat kesalahan $10 \%$. Keterlibatan masyarakat lokal dalam kegiatan wisata di kawasan wisata MKI yaitu: terlibat sebagai tenaga kerja, sebagai penyedia jasa dan pedagang di kawasan wisata, sebagai penyedia lahan, dan kelompok masyarakat yang tidak terlibat aktif di kawasan wisata. Keluarga yang terlibat dalam kegiatan wisata diambil secara menyeluruh dan keluarga yang tidak terlibat kegiatan wisata diambil secara acak (random sampling).

Data terkait dengan perkembangan wisata yang digunakan yaitu jumlah pengunjung dan fasilitas terbangun pendukung kegiatan wisata. Data terkait dengan keterlibatan masyarakat yaitu jenis keterlibatan dan jumlah keluarga yang terlibat. Data persepsi masyarakat terkait dengan dampakdampak yang ditimbulkan dikumpulkan dengan kuesioner (skala Likert) meliputi aspek sosial, ekonomi, dan lingkungan. Analisis hasil menggunakan analisis distribusi frekuensi dari skala Likert dan dideskripsikan berdasarkan pengamatan dan hasil wawancara terhadap Kepala Dusun Mudal.

\section{HASIL DAN PEMBAHASAN}

\section{Perkembangan Kawasan Wisata Museum Karst Indonesia}

MKI merupakan salah satu museum yang mengambarkan kondisi karst dan kehidupannya 
yang ada di Indonesia maupun di dunia. MKI dibangun atas prakarsa Kementerian Energi dan Sumber Daya Mineral (ESDM) cq Badan Geologi bersama dengan Pemerintah Provinsi Jawa Tengah, dan Pemerintah Kabupaten Wonogiri pada tahun 2008. Adanya dua pihak pengelola yang berbeda dalam satu kawasan tersebut tidak menjadikannya sebagai penghambat dalam upaya pengembangan wisata di Kawasan Wisata MKI tersebut. Hal ini ditunjukkan dengan kondisi yang harmonis diantara kedua institusi tersebut sejak pembangunan tahun 2009 sampai dengan tahun 2017 dalam mengelola sesuai dengan kewenangannya masing-masing.

MKI memiliki tiga fungsi utama. Fungsi yang pertama yaitu sebagai tempat pengumpulan dan pengarsipan benda bernilai yang berkaitan dengan karst dan kawasan karst pada umumnya. Fungsi yang ke-dua yaitu sebagai tempat untuk sarana pendidikan, penelitian, dan rekreasi mengenai karst di Indonesia. Fungsi yang ke tiga yaitu sebagai sarana pemeliharaan dan perlindungan warisan alam dan budaya. Selain ketiga fungsi tersebut juga tidak melupakan fungsi yang terkait dengan sosial ekonomi, yaitu memberikan manfat untuk masyarakat sekitar.

Objek wisata ini menjadi alternatif destinasi wisata di bentang lahan karst yang ada di Wonogiri bagian selatan, khususnya di Dusun Mudal, Desa Gebangharjo, Kecamatan Pracimantoro. Daya tarik wisata di lokasi penelitian yaitu wisata buatan berupa Museum dan wisata alam berupa bentang lahan karst yang mengelilingi museum. Kegiatan di dalam museum berupa kegiatan dalam ruangan (indoor) sedangkan kegiatan di luar ruangan (outdoor) berupa kunjungan ke geosite goa. Kawasan wisata MKI dapat berfungsi sebagai tempat untuk belajar (fungsi edukasi) maupun rekreasi. Sebagian besar wisatawan yang berkunjung adalah siswa sekolah, mahasiswa perguruan tinggi, dan keluarga. Wisata edukasi atau pendidikan adalah suatu program dimana peserta kegiatan wisata melakukan perjalanan wisata pada suatu tempat tertentu dalam suatu kelompok dengan tujuan utama mendapatkan pengalaman belajar secara langsung terkait dengan lokasi yang dikunjungi. Kegiatan luar ruangan (outdoor) berupa kunjungan ke geosite. Beberapa geosite yang ada di dalam kawasan wisata MKI terdiri dari goa dan luweng. Bentang lahan karst dan kehidupan masyarakatnya yang dapat menjadi bahan pembelajaran nyata bagi para wisatawan di luar museum. Beberapa objek (geosite) yang ada di kawasan wisata MKI dapat dilihat pada Gambar 1.

Taman bermain yang berada di depan Goa Sodong dan di dekat pintu masuk kawasan dibangun pada tahun 2017 oleh Dinas Kepemudaan, Olahraga dan Pariwisata Wonogiri. Taman ini juga menjadi daya tarik bagi wisatawan terutama pada saat sore hari. Karakteristik pengunjung yang ada di MKI beragam, mulai dari siswa sekolah, mahasiswa, keluarga, atau kelompok-kelompok masyarakat.

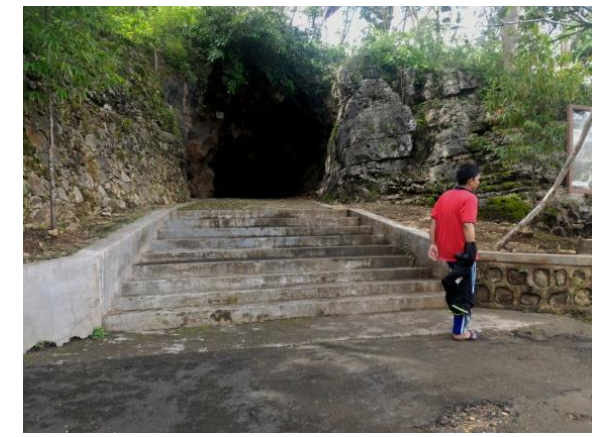

(a)

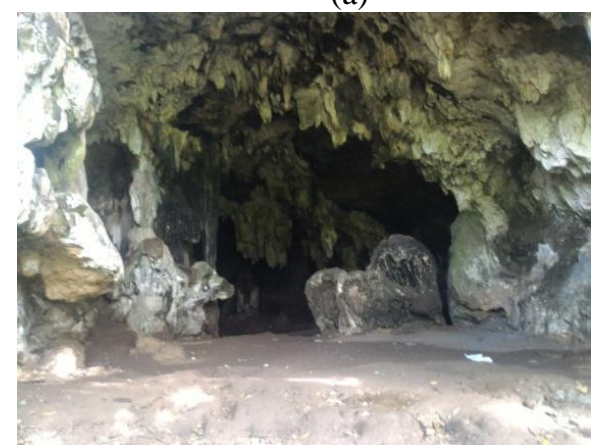

(c)

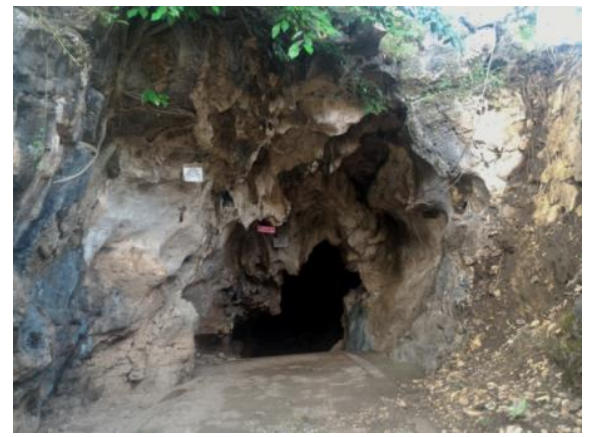

(b)

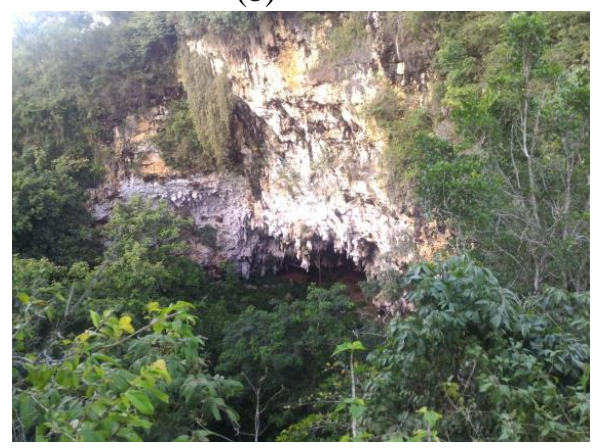

(d)

Gambar 1. Foto lokasi (a dan b) Goa Tembus, (c). Goa Potro Bunder dan (d), Goa Gilap. 


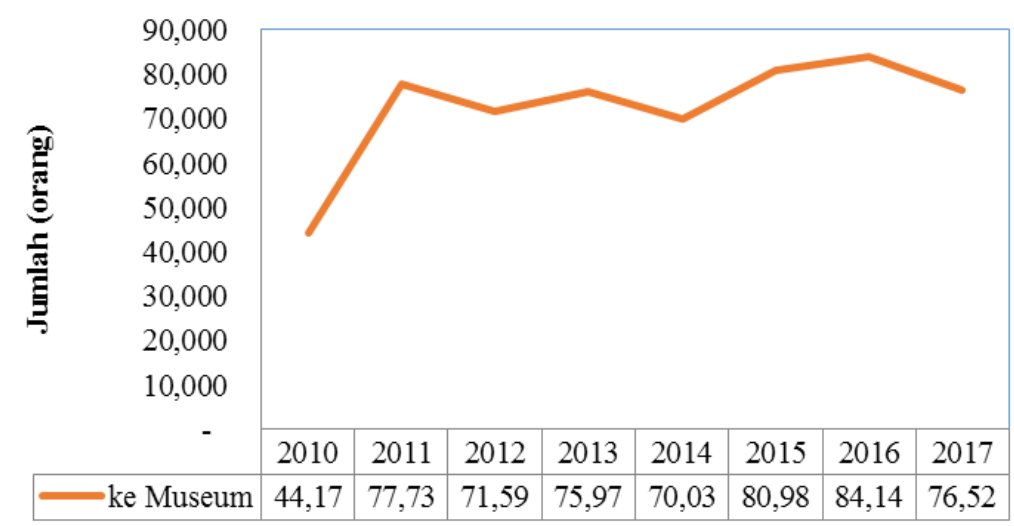

Gambar 2. Tren Kunjungan Wisatawan ke MKI. Sumber: Museum Karst Indonesia, 2018.

Tabel 1. Kontribusi penerimaan retribusi kawasan wisata MKI terhadap penerimaan pendapatan daerah dari sektor pariwisata Kabupaten Wonogiri.

\begin{tabular}{ccc}
\hline Tahun & Retribusi (Rp.) & Persentase dari pendapatan sektor pariwisata (\%) \\
\hline 2012 & $126,190,500$ & 10,94 \\
2013 & $110,868,800$ & 10,94 \\
2014 & $149,063,300$ & 11,76 \\
2015 & $154,334,000$ & 11,90 \\
2016 & $156,437,000$ & 13,78 \\
2017 & $279,942,000$ & 9,32 \\
\hline
\end{tabular}

Sumber: Dinas Kepemudaan Olahraga dan Pariwisata Wonogiri, 2018.

Tren kunjungan ke kawasan wisata MKI seperti terlihat pada Gambar 3 yaitu meningkat. Potensi kunjungan yang besar pada tahun 2016 ini dapat terus meningkat pada tahun 2017, tetapi pada bulan November 2017 terjadi bencana alam. Bencana alam banjir menyebabkan kerusakan bangunan dan benda koleksi MKI, sehingga terjadi penurunan jumlah kunjungan yang signifikan. Jumlah pengunjung museum pada tahun 2017 mencapai 76.520 orang pengunjung, lebih rendah dibanding pada tahun 2016, tetapi tetap masih lebih tinggi dibandingkan dengan tahun 2012- 2015. Perkembangan jumlah pengunjung berkaitan dengan perkembangan pendapatan daerah dari sektor pariwisata. Pada Tabel 1 disajikan kondisi penerimaan pendapatan daerah yang berasal dari kawasan wisata MKI.

Suatu kawasan wisata ataupun keberadaan objek wisata mengalami perubahan secara terus menerus bersifat dinamis termasuk dalam jumlah kunjungan maupun penerimaan retribusi. Operasional kawasan wisata MKI yang baru dimulai pada tahun 2010 dan masih terus dilakukan kegiatan pembangunan kelengkapan fasilitas serta daya taris wisata oleh pihak pengelola kawasan. Hal ini menjadi penanda bahwa tahapan perkembangan pariwisata di kawasan wisata MKI ini masih berada pada tahap awal perkembangan yang menurut urutan tahapan perkembangan model Butler's (1980) berada pada antara tahap pretourism (penemuan) menuju tahap ke dua yaitu keterlibatan masyarakat lokal dalam kegiatan wisata.
Tahap penemuan dalam model Butler's digambarkan sebagai kondisi dimana terdapat sejumlah pengunjung yang memulai pengalaman berkunjung dan secara tidak langsung informasi keberadaan objek wisata tersebut semakin dikenal luas oleh masyarakat. Pada tahap awal perkembangan ini mulai muncul sejumlah peluang ekonomi yang ditangkap oleh masyarakat lokal. Peluang-peluang yang muncul yaitu dalam hal pemenuhan kebutuhan dasar para wisatawan. Tahap ini ditandai dengan mulai adanya peningkatan jumlah pengunjung dan munculnya inisiasi warga lokal untuk memenuhi kebutuhan wisatawan. Kegiatan pembangunan masih berlangsung untuk melengkapi fasilitas-fasilitas yang dibutuhkan untuk mendukung perkembangannya. Pada tahap ini belum ada promosi wisata yang gencar. Promosi yang dilakukan oleh pihak pengelola masih dirasa kurang dan baru berada pada lingkup sekolahsekolah di Kabupaten Wonogiri. Promosi menggunakan media elektronik termasuk media sosial juga belum banyak dilakukan.

\section{Keterlibatan Masyarakat dalam Kegiatan Wisata}

Rumah tangga/ keluarga yang berinisiatif membuka usaha dengan berjualan di kawasan wisata MKI dari tahun ke tahun mengalami peningkatan jumlah. Peningkatan tersebut dapat dilihat pada Gambar 3. 
Tabel 2. Penginapan yang ada di Dusun Mudal.

\begin{tabular}{clccc}
\hline No. & \multicolumn{1}{c}{ Nama penginapan } & Alamat & Tahun mulai & Kondisi \\
\hline 1 & Pratitis & RT 2 Mudal & 2009 & Aktif \\
2 & Ngudi Mulyo & RT 2 Mudal & 2009 & Tidak aktif \\
3 & Muja Rejeki & RT 4 Mudal & 2010 & Tidak aktif \\
4 & Bunga Melati & RT 4 Mudal & 2010 & Tidak aktif \\
5 & Rumah Bapak Lilik Murdiyanto & RT 4 Mudal & 2010 & Tidak aktif \\
6 & Rumah Bapak Ariantoko & RT 4 Mudal & 2013 & Tidak aktif \\
\hline
\end{tabular}

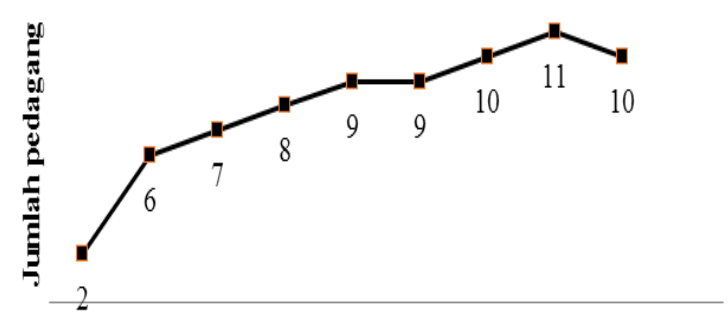

200920102011201220132014201520162017

Tahun

Gambar 3. Grafik jumlah pedagang di kawasan wisata MKI.

Keterlibatan masyarakat dalam kegiatan pendukung wisata sebagai pedagang mengalami peningkatan walaupun jumlahnya masih terhitung kecil. Jumlah pedagang yang ada di kawasan wisata MKI terdiri dari pedagang yang berlokasi di dalam kawasan sekitar museum, di kawasan pintu masuk kawasan dan di rumah-rumah tempat tinggalnya. Mayoritas pedagang membuka usahanya pada harihari ramai kunjungan wisata yaitu pada hari Sabtu dan Minggu. Beberapa pedagang membuka kios atau warung selama 7 hari dalam satu mingggunya tanpa ada hari libur. Beberapa pedagang tersebut menjadikan usahanya sebagai mata pencaharian yang utama. Pedagang tersebut berpendapat bahwa walaupun museum libur namun konsumen juga ada yang berasal dari daerah sekitar.

Mayoritas penjual di kawasan wisata MKI ini yaitu ibu-ibu sebanyak $72 \%$ dan semuanya berasal dari Dusun Mudal. Sebanyak (28\%) pedagang berasal dari luar Mudal dan dilakukan oleh Lakilaki. Wanita memiliki peran yang penting dalam pengembangan sektor pariwisata melalui keterlibatan dalam berbagai kegiatan pendukung wisata (Utami, 2013). Istri dapat berperan dalam peningkatan kesejahteraan suatu rumah tangga. Kondisi sumberdaya yang terbatas mendorong istri ikut berperan dalam memenuhi kebutuhan hidup keluarganya dengan cara ikut bekerja. Pekerjaan yang diambil sebagai upaya membantu suami (kepala keluarga) dapat dalam kegiatan pertanian, peternakan, maupun perdagangan (Hastuti dan Suhardjo, 2016). Peran istri dalam rumah tangga di daerah perdesaan secara umum yaitu sebagai ibu rumah tangga, namun di Dusun Mudal ini istri juga terlibat dalam kegiatan wisata sebagai pedagang.

Keterlibatan masyarakat sebagai pedagang di sekitar kawasan wisata masih terlihat rendah. Rendahnya keterlibatan masyarakat lokal dalam berbagai kegiatan pendukung wisata menurut Utami (2013) dapat disebabkan karena keterbatasan sumberdaya yang ada, termasuk dalam hal pendanaan. Pedagang yang ada di sekitar kawasan wisata MKI pada umumnya menjajakan makanan dan minuman, dimana bahan-bahan tersebut diperoleh dari Pasar Pracimantoro.

Usaha jasa penginapan di Dusun Mudal tidak berkembang dengan baik. Hal ini terlihat dari kondisi usaha tersebut yang tidak aktif. Terdapat beberapa rumah yang sekaligus diperuntukkan sebagai penginapan tetapi sudah lama tidak ada wisatawan yang menggunakannya. Berdasarkan pengamatan yang dilakukan terhadap usaha jasa penginapan di sekitar kawasan wisata MKI (Tabel 2) menunjukkan bahwa pada umumnya pemilik penginapan tidak mengetahui seluk-beluk usaha jasa penginapan tersebut. Sebanyak 5 (lima) pemilik penginapan $(83,33 \%)$ bersifat tidak aktif dan hanya ada satu rumah tangga $(16,67 \%)$ yang masih tetap aktif.

Keberadaan penginapan di Dusun Mudal ini belum dapat berkembang dengan baik dikarenakan tidak adanya wisatawan yang singgah atau bermalam di lingkungan kawasan wisata MKI tersebut. Usaha jasa penginapan dapat tumbuh dan berkembang seiring dengan banyaknya wisatawan yang singgah di suatu tempat wisata (Sari, 2016). Karakteristik wisatawan yang hanya menghabiskan sedikit waktu di kawasan wisata MKI dan tidak adanya atraksi lain yang menarik wisatawan untuk berlama-lama. Hal inilah yang menjadi salah satu penyebab tidak berkembangnya usaha jasa penginapan di sekitar Kawasan Wisata MKI.

Kehidupan sehari-hari masyarakat Dusun Mudal tidak semuanya berhubungan dengan kegiatan yang ada di kawasan wisata MKI. Berdasarkan keterlibatan masyarakat dalam kegiatan pendukung di kawasan wisata yang kecil persentasenya, maka dapat diasumsikan bahwa tidak semua masyarakat memiliki akses terhadap pengelola kawasan wisata. Rumah tangga yang terlibat dalam kegiatan berjualan di sekitar kawasan 
wisata maupun sebagai tenaga kerja tentu memiliki hubungan yang lebih dekat dibandingkan dengan keluarga yang tidak memiliki hubungan sama sekali.

\section{Dampak Terhadap Kondisi Sosial Masyarakat}

Dampak terhadap kondisi sosial mastarakat lokal (Dusun Mudal) masih kecil (Tabel 3). Interaksi yang terjadi antara pengunjung wisata dan masyarakat Dusun Mudal tidak banyak terjadi atau hanya terjadi dalam waktu yang singkat. Kekhawatiran masyarakat terhadap gangguangangguan dalam aspek sosial pada umumnya dalam hal sikap dan perilaku wisatawan yang berada di kawasan wisata MKI. Perilaku wisatawan dimungkinkan menimbulkan dampak negatif karena adanya perbedaan kebiasaan dalam berhubungan dengan masyarakat lokal. Adanya kawasan wisata yang berada di kawasan karst juga dimanfaatkan oleh pemuda pemudi dari daerah lain untuk bersantai-santai.

Masyarakat Dusun Mudal secara umum memiliki hubungan yang baik dengan pengelola kawasan wisata, baik dengan pengelola museum maupun kawasan wisata. Hubungan antara pengelola dengan masyarakat pada awal pembangunan sempat tidak berjalan dengan baik dikarenakan kurangnya komunikasi dan pelibatan masyarakat dalam pengadaan lahan kawasan wisata MKI. Pada awal operasional kawasan wisata MKI juga belum melibatkan para pemuda Dusun Mudal sehingga masyarakat memiliki persepsi negatif terhadap adanya kegiatan wisata di dusunnya. Kesulitan dalam penyampaian aspirasi kepada pengelola kawasan wisata maupun pengelola museum ditunjukkan dengan tidak adanya kotak saran masukan yang mudah diakses oleh masyarakat Dusun Mudal. Tidak semua masyarakat memiliki kemudahan dalam berkomunikasi dengan pengelola kawasan. Sebagian masyarakat di mana anggota keluarga memiliki keterkaitan dengan kegiatan wisata maka akan memiliki akses yang lebih terbuka untuk menyampaikan aspirasi atau permasalahan yang timbul di masyarakat. Rumah tangga yang terlibat dalam kegiatan berjualan di sekitar kawasan wisata maupun sebagai tenaga kerja tentu memiliki hubungan yang lebih dekat dibandingkan dengan keluarga yang tidak memiliki hubungan sama sekali.

Aspek sosial masyarakat yang terkait dengan hubungan antar masyarakat masih baik dan tidak terpengaruh dengan adanya perkembangan kawasa wisata MKI. Karakter kebersamaan antar masyarakat setempat masih sangat kuat, termasuk dalam hal kegotong royongan, kehadiran pertemuan, dan penggunaan bahasa lokal dalam bertegur sapa. Dampak lingkungan sosial yang mungkin dapat terjadi dengan adanya banyak orang yang datang ke Dusun Mudal yaitu munculnya tindak kejahatan berupa pencurian. Gambaran persepsi masyarakat dalam melihat dampak negatif tersebut dapat dilihat pada Gambar 4.

Kejadian pencurian karena adanya pengunjung sangat kecil atau tidak pernah dirasakan oleh masyarakat Mudal. Terdapat $12,9 \%$ warga yang merasakan dengan adanya kawasan wisata ini menyebabkan peningkatan tindakan pencurian di Dusun Mudal. Menurut salah satu petugas keamanan dan kebersihan di kawasan wisata MKI pernah terjadi kasus pencurian di warung-warung atau kios penjual di dalam kawasan wisata. Kejadian tersebut dimungkinkan karena adanya wisatawan yang berperilaku tidak baik. Dusun Mudal pada dasarnya merupakan daerah yang aman, masyarakatnya masih rutin mengadakan kegiatan ronda malam. Keadaan dimana terjadi kasus pencurian ternyata tidak dirasakan oleh masyarakat Dusun Mudal secara umum. Sebanyak $82,26 \%$ warga tidak sependapat dengan pernyataan bahwa adanya kawasan wisata menyebabkan terjadinya peningkatan tindakan pencurian.

Menurut Hermawan (2016) kejadian pencurian di lokasi-lokasi wisata dapat terjadi apabila pengawasan yang dilakukan oleh pihak pengelola lemah. Kejadian pencurian apabila dibiarkan dan tidak dilakukan peningkatan pengamanan maka akan menjadi dampak negatif yang dirasakan masyarakat lokal maupun pelaku usaha di suatu kawasan wisata. Berdasarkan pengamatan di lokasi kawasan wisata MKI masih dirasa kurang dalam

Tabel 3. Dampak perkembangan kawasan wisata MKI terhadap kondisi sosial masyarakat.

\begin{tabular}{lcc}
\multicolumn{1}{c}{ Dampak sosial } & Frekuensi & Persentase $(\%)$ \\
\hline Kecil $(<18,61)$ & 32 & 51,61 \\
Sedang $(18,61-29,33)$ & 30 & 48,39 \\
Total & 62 & 100 \\
\hline
\end{tabular}

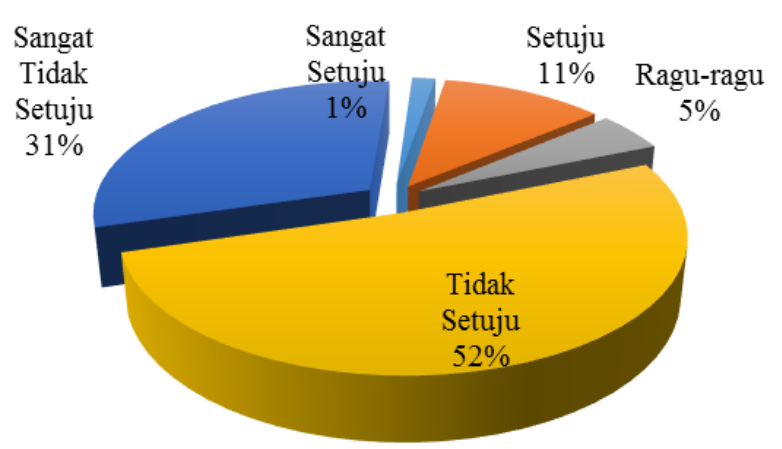

Gambar 4. Grafik persepsi masyarakat terkait dengan meningkatnya tindakan pencurian. 
hal pengamanannya. Petugas keamanan yang berada di museum hanya bertanggung jawab terhadap keamanan di dalam bangunan museum saja, sedangkan untuk kegiatan di luar ruangan (outdoor) masih lemah dalam hal pengawasannya. Peningkatan jumlah wisatawan yang tidak diimbangi dengan peningkatan pengawasan dan pengamanan maka dapat berpotensi terjadinya tindak kejahatan termasuk pencurian oleh oknum wisatawan kepada wisatawan lainnya maupun wisatawan kepada penduduk lokal di Dusun Mudal.

Persepsi masyarakat terkait dengan adanya dampak negatif berupa kenakalan remaja dan tindakan-tindakan yang tidak sesuai dengan norma dapat dilihat pada Gambar 5.

Keberadaan kawasan wisata MKI di Dusun Mudal yang luas berpotensi disalah gunakan oleh beberapa oknum pengunjung yang tidak bertanggung jawab. Pada Gambar 5 terlihat bahwa masyarakat yang memiliki persepsi negatif terhadap keberadaan kawasan wisata MKI sebesar 41,93\% terkait dengan kenalan remaja dan $43,54 \%$ terkait dengan munculnya tindakan asusila. Fenomena kenakalan remaja dan tindakan yang tidak sesuai dengan norma tersebut lebih banyak dilakukan oleh pengunjung usia remaja di dalam kawasan wisata. Masyarakat sering menemukan adanya muda mudi yang berduaan di lokasi-lokasi yang tersembunyi dan sepi. Masyarakat merasa resah dengan adanya kenakalan remaja seperti minum-minuman keras di lokasi sekitar goa atau tempat sepi di dalam kawasan wisata. Warga Mudal juga pernah menemukan alat kontrasepsi di dalam kawasan wisata. Hal-hal tersebut menjadi dampak negatif adanya kawasan wisata di Dusun Mudal. Hasil observasi di dalam kawasan wisata dijumpai sepasang muda mudi yang sedang berduaan di tempat yang sepi.

\section{Dampak Terhadap Kondisi Ekonomi Masyarakat Lokal}

Mayoritas masyarakat Dusun Mudal memiliki persepsi yang baik terkait dengan dampak ekonomi masyarakat (Tabel 4), sebesar $85,48 \%$ berada pada kategori sedang. Hal ini menunjukkan bahwa terjadi perubahan kondisi ekonomi ke arah peningkatan kondisi ekonomi masyarakat atau mengalami kemajuan perekonomian. Masyarakat memandang adanya kawasan wisata berdampak positif secara ekonomi. Pada beberapa indikator menunjukkan bahwa perubahan tersebut sebenarnya kecil terutama pada tumbuh berkembangnya sektor industri dan jasa (makanan, kerajinan, jasa penginapan). Dampak yang besar kemungkinan dirasakan bagi keluarga yang memiliki kesempatan untuk bekerja dan berusaha di kawasan wisata MKI, sehingga mendapatkan keuntungan berupa peningkatan pendapatan keluarga.

Dari Tabel 5, terlihat bahwa keberadaan kawasan wisata MKI di Dusun Mudal telah mampu meningkatkan kondisi ekonomi keluarga sebesar 8,7\% dari total keluarga/ rumah tangga di Dusun Mudal. Angka ini tentunya masih sangat kecil apabila dibandingkan dengan jumlah keluarga yang ada di Dusun Mudal. Warga masyarakat yang terlibat dalam kegiatan pendukung wisata masih

Tabel 4. Dampak perkembangan kawasan wisata MKI terhadap kondisi ekonomi masyarakat.

\begin{tabular}{lll}
\hline Dampak ekonomi & Frekuensi & $\begin{array}{l}\text { Persentase } \\
(\%)\end{array}$ \\
\hline Kecil $(<16,33)$ & 4 & 6,45 \\
Sedang $(16,33-25,67)$ & 53 & 85,48 \\
Besar $(<25,67)$ & 5 & 8,06 \\
Total & 62 & 100 \\
\hline
\end{tabular}

Tabel 5. Persentase peningkatan kondisi ekonomi di Dusun Mudal.

\begin{tabular}{lll|cc|}
\hline & & & \multicolumn{2}{c|}{ Persentase } \\
No. & Penggunaan hasil usaha & Frekuensi & $\begin{array}{c}\text { Pelaku usaha } \\
(\%)\end{array}$ & $\begin{array}{c}\text { Terhadap total keluarga di } \\
\text { Ds. Mudal }\end{array}$ \\
\hline 1 & Untuk meningkatkan kapasitas usaha & 2 & 14,29 & 1,24 \\
2 & Untuk tambahan tabungan keluarga & 3 & 21,43 & 1,86 \\
3 & Untuk pemenuhan kebutuhan sehari-hari saja & 9 & 64,29 & 5,59 \\
& Total & & 100 & 8,7 \\
\hline
\end{tabular}
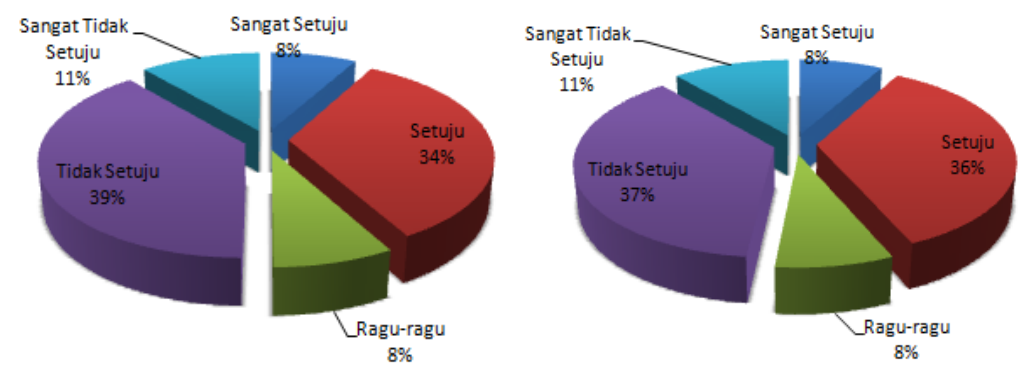

Gambar 5. Persepsi masyarakat tentang munculnya kenakalan remaja (kiri) dan tindakan asusila (kanan). 
terbatas pada keluarga yang terlibat dalam pengadaan lahan. Berdasarkan data yang dikumpulkan terkait dengan kondisi ekonomi keluarga, mereka mengaku bahwa terjadi peningkatan secara ekonomi. Peningkatan tersebut diwujudkan dalam beberapa alternatif penggunaan. Persentase terbesar $(64,29 \%)$ hasil dari usaha di bidang pendukung wisata baru cukup untuk pemenuhan kebutuhan sehari-hari. Keluarga yang merasakan hasil usaha selain untuk pemenuhan kebutuhan sehari-hari telah mampu menyisihkan sebagian pendapatannya tersebut untuk peningkatan kapasitas usaha $(14,29 \%$ pelaku usaha) dan untuk tambahan tabungan keluarga sebanyak 21,43\% dari keseluruhan pelaku usaha. Secara umum dampak positif yang dirasakan belum bisa mencakup semua kalangan yang ada di Dusun Mudal.

Berdasarkan pada persentase keterlibatan masyarakat dapat dianalisis bahwa peluang bekerja di kawasan wisata MKI sangat terbatas. Perubahan struktur mata pencaharian di Dusun Mudal dengan adanya kawasan wisata ini masih termasuk kecil. Perubahan yang terjadi dari mata pencaharian sebagai petani beralih ke tenaga kerja kontrak di kawasan wisata MKI. Para tenaga kerja yang diterima di kawasan wisata MKI tetap memiliki lahan pertanian sebagai sumber pendapatan mereka.

Masyarakat Mudal memiliki perspsi yang beragam terkait dengan peningkatan pendapatan. Tidak semua keluarga di Mudal merasakan dampak positif ini (sebesar 46,78\%) sedangkan 45,16\% menyatakan adanya dampak positif peningkatan pendapatan keluarga. Perekonomian di Mudal dapat terangkat walaupun hanya terjadi pada sebagian rumah tangga/ keluarga. Dampak positif ini apabila dikaitkan dengan keterlibatan warga dalam kegiatan pendukung di kawasan wisata memang tidak tinggi. Analisis terkait dengan peningkatan pendapatan ini berlaku terhadap keluarga atau rumah tangga. Pada pembahasan dampak peningkatan pendapatan, terdapat keluarga yang mendapat tambahan pendapatan dari anggota keluarga (suami) yang bekerja di museum maupun kawasan wisata dan anggota keluarga yang lain (istri) membuka usaha di dalam kawasan sebagai pedagang. Sebagian keluarga lainnya mendapatkan tambahan penghasilan keluarga dari berjualan saja.

\section{Dampak Terhadap Kondisi Fisik Lingkungan}

Kondisi lingkungan fisik di dalam kawasan wisata MKI maupun di lingkungan sekitarnya masih dirasa tidak menggangu bagi masyarakat sekitar kawasan wisata. Enam poin pertanyaan yang diberikan kepada masyarakat didapatkan hasil bahwa secara umum dampak yang ditimbulkan dari aspek fisik lingkungan termasuk kategori kecil
Tabel 6. Dampak perkembangan kawasan wisata MKI terhadap fisik lingkungan di Dusun Mudal.

\begin{tabular}{lll}
\hline Dampak fisik lingkungan & Frekuensi & Persentase (\%) \\
\hline Kecil $(<14)$ & 33 & 53,23 \\
Sedang (14-22) & 26 & 41,94 \\
Besar $(>22)$ & 3 & 4,84 \\
Total & 62 & 100 \\
\hline
\end{tabular}

$(53,23 \%)$ dan sedang $(41,94 \%)$. Hal ini seperti ditunjukkan pada Tabel 6, menunjukkan bahwa perubahan ke arah negatif yang dirasakan masyarakat Mudal tidak terasa secara luas.

Karakteristik sampah yang ditimbulkan di kawasan wisata MKI yaitu kertas dan plastik bungkus makanan dan minuman. Sampah padat berasal dari kegiatan makan dan minum pengunjung dan kegiatan berdagang. Pengelolaan yang dilakukan yaitu hanya dengan membuang di TPA di dalam kawasan dan tidak ada pemilahan jenis-jenis sampah seperti yang ada pada tempat sampah yang sudah disediakan sesuai dengan jenis sampahnya. Sampah padat selain dihasilkan oleh pengunjung juga dihasilkan dari aktivitas berjualan yang dilakukan oleh masyarakat Dusun Mudal. Semua penjual yang ada di kawasan wisata menghasilkan sampah padat berupa plastik, dan sebagian menghasilkan sampah organik. Jenis sampah yang dominan yaitu sampah plastik dan sedikit sampah organik. Pedagang melakukan pengelolaan sampah dengan mengumpulkannya dan diangkut oleh petugas kebersihan ke TPA.

Permasalahan yang mungkin akan timbul untuk jangka panjang yaitu semakin banyaknya sampah padat yang ditumpuk di TPA, sedangkan tidak ada pengelolaan lebih lanjut terhadap sampahsampah tersebut. Lokasi TPA sampah yang berada di lereng bagian atas dapat berdampak pada timbulnya pencemaran air dan udara di bagian bawah lereng/ lahan. Kontur lahan pembuangan sampah yang miring kea rah lahan pertanian akan berdampak pada lahan pertanian yang ada, dimana pada musim hujan air lindi yang ada di TPA dapat terbawa menuju ke bagian bawah bersama dengan air hujan. Secara estetika adanya TPA di bagian ujung kawasan wisata ini juga tidak bagus, apalagi lokasinya berdekatan dengan Goa Gilap.

\section{KESIMPULAN}

Kawasan wisata Museum Karst Indonesia (MKI) masih berada pada tahap awal perkembangan ditandai dengan aktifnya kegiatan pembangunan fisik dan mulai adanya keterlibatan masyarakat lokal dalam kegiatan wisata. Keterlibatan masyarakat lokal (Dusun Mudal) masih rendah, kesempatan terbatas pada anggota 
keluarga atau kerabat dari warga yang terlibat dalam penyediaan lahan untuk kawasan wisata. Dampak perkembangan kawasan wisata MKI terhadap kondisi sosial, ekonomi dan lingkungan fisik masih termasuk kecil.

Keterlibatan masyarakat dalam kegiatan pendukung wisata di kawasan wisata MKI perlu ditingkatkan dengan membuka akses seluas-luasnya bagi seluruh masyarakat Dusun Mudal, Desa Gebangharjo. Menambah atraksi-atraksi wisata sehingga mampu meningkatkan jumlah pengunjung dan dapat berdampak positif terhadap peningkatan pendapatan masyarakat. Timbulan sampah padat dari kegiatan wisata perlu dikelola dengan baik bekerjasama dengan masyarakat lokal Dusun Mudal. Pengawasan dan pengamanan kawasan wisata MKI masih perlu ditingkatkan untuk meminimalkan tindakan yang tidak sesuai dengan norma kesusilaan oleh pengunjung. Dilakukan evaluasi secara berkala terhadap perkembangan kawasan dan dampak-dampak yang ditimbulkannya sehingga apabila muncul dampak negatif dapat segera dikelola.

\section{DAFTAR PUSTAKA}

Amelia, D.F., 2015. Upaya Pemerintah Indonesia Menjadikan Kawasan Gunung Sewu Sebagai Unesco Global Geopark Network (GGN) Tahun 2013-2015. JOM Fisip, 3(2):1-14.

Briassoulis, H., dan van der Straaten, J., 2009. Tourism and the Environment: Regional, Economic and Policy Issues, Springer, New York.
Hastuti dan Suhardjo, A.J., 2016. Keterkaitan Lingkungan Geografi, Kondisi Sosial Ekonomi dan Pembagian Kerja Secara Seksual di Perdesaan. Majalah Geografi Indonesia. 20(20:94-113.

Hermawan, H., 2016. Dampak Pengembangan Desa Wisata Nglanggeran Terhadap Ekonomi Masyarakat Lokal. Jurnal Pariwisata (2):105117.

Nugroho, I., 2011. Ekowisata dan Pembangunan Berkelanjutan, Yogyakarta: Pustaka Pelajar.

Nugroho, W.J., Gandasasmita, K. dan Manuwoto, 2015. Arahan Pengembangan Obyek Wisata Menuju Pembangunan Pariwisata Berkelanjutan di Kabupaten Wonogiri. Jurnal Kawistara, 5(3):221-228.

Sari, R., 2016. Pemberdayaan Masyarakat Melalui Pengembangan Usaha Pariwisata (Meneropong Usaha Penginapan Masyarakat Lokal dan Manca Negara di Desa Mon Ikeun Lhoknga). Jurnal Al-Bayan, 22(34):53-64.

Supardi, I., 2003. Lingkungan Hidup \& Kelestariannya. Edisi ke-2. Bandung: PT. Alumni.

Theobald, W.F., 2005. Global Tourism. Third Edition. Amsterdam:Elsevier Inc.

Utami, S.M., 2013. Keterlibatan Masyarakat Lokal dalam Pengembangan Potensi Wisata di Kabupaten Semarang. Forum Ilmu Sosial, 40(1):84-96.

Williams, S., and Alan, A.L. 2015. Tourism Geography: Critical Understandings of Place, Space and Experience (Third). New York: Routledge. 